\title{
Pectinase Producers from Rotten Fruits and Vegetable Samples: Isolation, Screening and Characterization
}

\author{
Fatima Anjum¹, Rashida Rahmat Zohra², Mahnaz Ahmad ${ }^{1}$, \\ Raheela Rahmat Zohra ${ }^{1}$ \\ ${ }^{1}$ Department of Biotechnology, University of Karachi, Karachi-75270, Pakistan \\ ${ }^{2}$ Department of Biotechnology, Jinnah University for Women, Karachi - 74600, Pakistan
}

\begin{abstract}
Pectinases are one of the essential group of enzymes in the field of biotechnology and has applications in various industries including food, textile, paper industries and waste management. In this study, indigenous bacterial pectinase producers have been isolated from rotten fruits and vegetables (tomato, mango, peach and cabbage) on Luria agar. Sixty-six bacterial strains were screened out as potential pectinase producers among hundred and seventeen isolates. Screening of these pectinase producers were subjected to three parameters (temperature, pectin concentration and time). Seven strains were screened out to be potential thermotolerant and high pectin concentration utilizing strains among which isolate no. 72 gave better results than other strains. Morphological and biochemical tests were performed to identify bacterial pectinase producers, majority of which were identified as Bacillus sp.
\end{abstract}

Keywords: Bacterial Pectinase, Isolation, Screening, Characterization

\section{Introduction}

Pectin is complex negatively charged heteropolysaccharide and is major component of cell wall of plants. Pectic substances contribute $0.5-4 \%$ of fresh weight of plant materials. (Jayani et al., 2005). Pectin are bio-converted into its simpler and high value end products by pectinases based on substrate specificity and specific catalytic mechanism (Kholi et al., 2015).

Pectinases are commonly employed in food industry for clarification of fruit juices, preparation of functional foods, fruits and vegetable processing, animal feed industry, processing of wine and fermentation of tea, coffee and cocoa beans (Deng et al., 2019; Sharma et al., 2017; Amin et al., 2017; Kashyap et al., 2001). In textile industry,

\section{Materials and methods:}

Sample Collection:

Rotten fruits and vegetables samples (rotten mango, rotten tomato, rotten peach, and rotten cabbage) were collected from fruits and vegetable stalls of Karachi, Pakistan.

\section{Isolation and Purification:}

Rotten fruits and vegetable samples were serially diluted and spread plated on Luria agar $(\mathrm{g} / \mathrm{L})$ : Tryptone 10, Sodium Chloride 5, Yeast Extract 5, and pectinasesare involved in degumming and retting of fibre crops, bio-scouring processes for preparation of high quality of tensile yet soft fabrics. Bio-bleaching, bio-pulping using pectinases have revolutionized paper industry (Chahta et al., 2017; Garg et al., 2016). Pectinases are also involved in manufacturing of prebiotics, medicinal formulations and waste water treatment (Shet et al., 2018).

Considering vast applications of pectinase, it is necessary to meet the increasing demand of pectinases. Present study has been conducted to explore local bacterial strains isolated from rotten fruits and vegetable samples as potential pectinase producers of Pakistan.

Agar 15. The plates were incubated at $37^{\circ} \mathrm{C}$ for 24 hours. Cultures were further purified by successive quadrant streak method. Master plates of pure cultures obtained were spot inoculated on Luria agar plates using sterile pinpointed toothpicks.

\section{Screening of Pectinase:}

Pectinase plate screening assay was performed by spot inoculation of cultures on Pectinase Screening Media (PSM) containing (g/L): Tryptone 10, Citrus Pectin 5, Sodium Chloride 5, Yeast Extract 5, and 
Agar 15. Each pure culture was spot inoculated on PSM agar plates and incubated at $37^{\circ} \mathrm{C}$ for 24 hours.

\section{Pectinase Screening Assay/ Detection Method:}

Colony sizes were measured. Surface of the plate was flooded with Gram`s Iodine solution for 10 minutes and zone of hydrolysis were measured (Soares et al., 1999). Enzymatic Index (EI) was calculated for each bacterial culture by following formula:

Enzymatic Index = Zone Size of Hydrolysis/ Colony Size

\section{Effect of Incubation Temperature:}

Each pectinase producing bacterial strains were carefully spot inoculated on PSM agar plate and were incubated at different temperatures i.e. $37^{\circ} \mathrm{C}, 40^{\circ} \mathrm{C}$, $45^{\circ} \mathrm{C}, 50^{\circ} \mathrm{C}, 55^{\circ} \mathrm{C}, 60^{\circ} \mathrm{C}, 65^{\circ} \mathrm{C}, 70^{\circ} \mathrm{C}$ and $75^{\circ} \mathrm{C}$ for 24 hours. Enzyme index was determined for each strain.

\section{Effect of Substrate Concentration:}

Strains were spot inoculated on PSM plates with varying concentrations of pectin $(\mathrm{g} / \mathrm{L})$ : $5,10,15,20$ and 25. All plates were incubated at $37^{\circ} \mathrm{C}$ for 24 hours. Pectinase screening assay by the calculation of enzyme index for each strain was performed.

\section{Effect of Incubation Time:}

Cultures were spot inoculated on PSM agar plates. Inoculated plates were incubated at $37^{\circ} \mathrm{C}$ for different incubation time i.e. 24 hours, 48 hours, 72 hours, 96 hours and 120 hours. Pectinase screening assay was performed to determine enzyme index.

\section{Morphological, Biochemical and Physiochemical Characterization of Strains:}

The morphological, biochemical and physiochemical tests performed for the characterization of pectinase producing strains were gram straining, colonial and morphological characteristics, oxygen requirement (growth pattern in broth), catalase, IMViC and carbohydrate fermentation tests for glucose, maltose, lactose, mannitol, sucrose, xylose and glycerol.

\section{Results and Discussion \\ Sampling, Isolation and Purification:}

Rotten fruits and vegetable samples were selected in this study with the aim of screening of potential local bacterial pectinase producing strains that could be potentially utilized for production and usage of pectinase in different industries (Figure 1). Hundred and seventeen pure bacterial cultures were isolated from rotten fruits and vegetables on defined media.
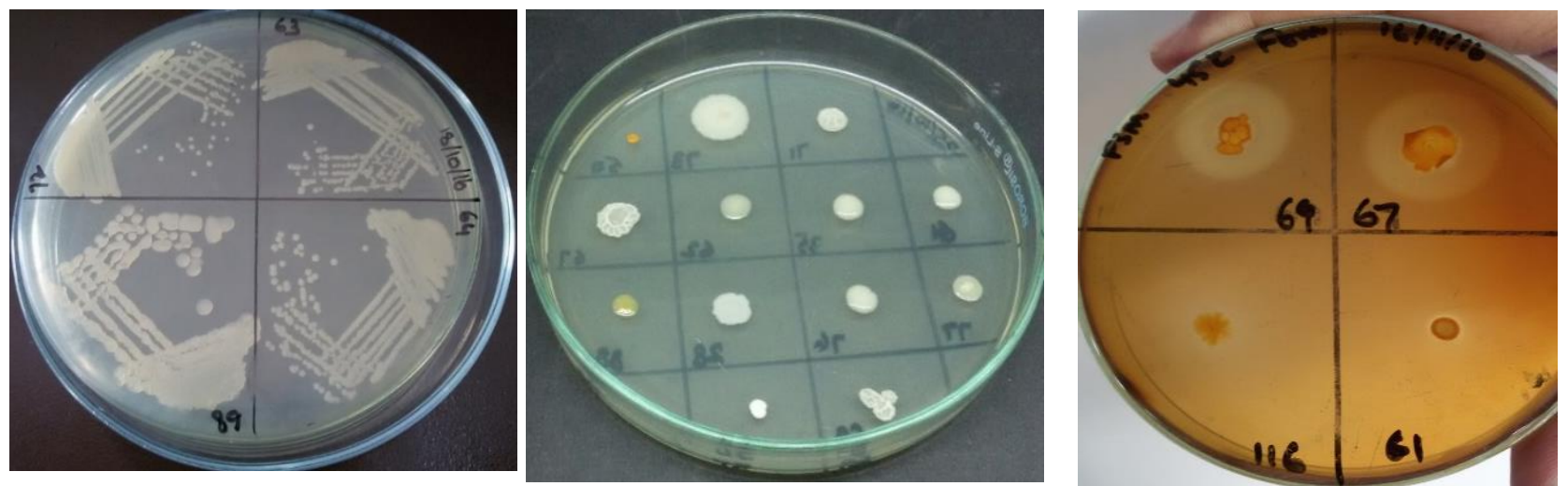

Figure 1: From left to right (A) Isolation, (B) Master Plate/ Maintenance of cultures (C) Pectinase Activity

Many studies reported the isolation and screening of pectinolytic bacteria from spoiled fruits and vegetable samples (Sohail \& Latif, 2016; Parveen et al., 2017) including tomato (Obafemi et al., 2019), mango (Reddy\& Saritha, 2015), peaches (Mahesh et al., 2016) and cabbage (Rehman et al., 2015).

This study is focused on isolation and screening of bacterial pectinase producers which have diverse application in different industries (Kashyap et al., 2001). Pectinases are produced by other microbes also (Sindhu et al., 2017; Li et al., 2015; Ortiz et al., 2017;
Ahmed et al., 2016). Majority of Bacterial isolates produce alkaline pectinase (Kavuthodi et al., 2018) with few exceptions producing acidic pectinase (Yu \& $\mathrm{Xu}, 2018)$.

\section{Screening of Pectinase:}

Sixty-six cultures were found to be pectinase producer among total of hundred and seventeen bacterial isolates. Majority of the strains were isolated from rotten tomato $(51.5 \%)$ and rotten mango $(36.4 \%)$ (Figure 2). 


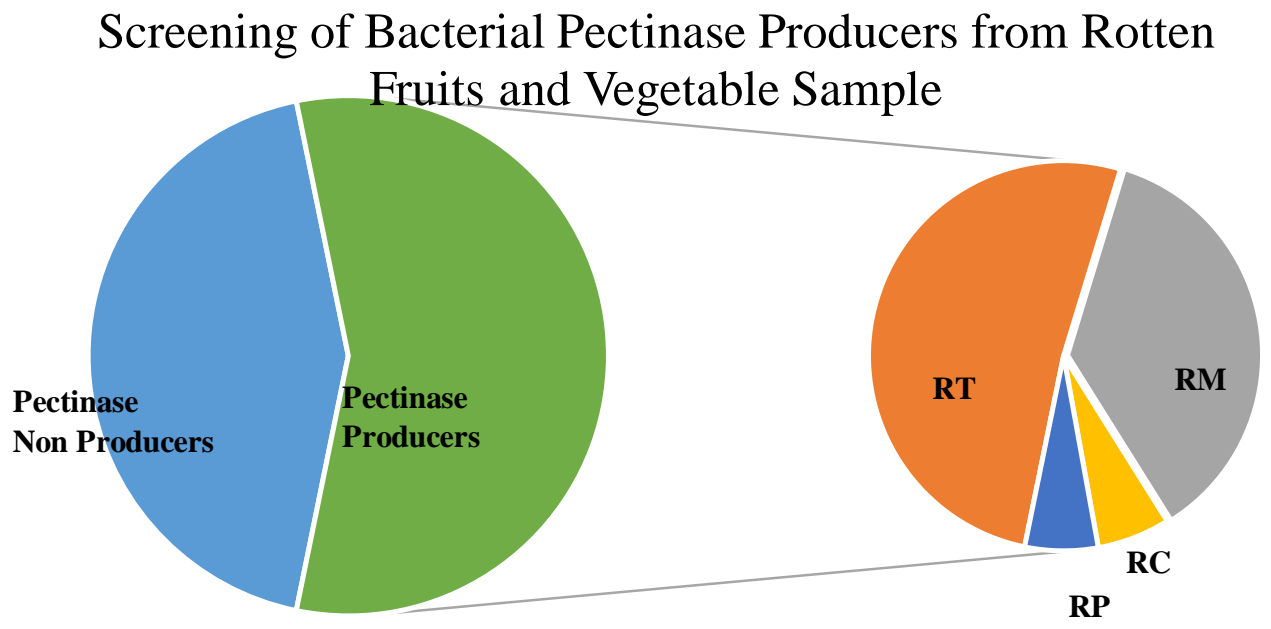

Figure 2: Overview of screening of bacterial pectinase producers (66 isolates) from 117 bacteria isolated from rotten tomato RT (34 isolates), rotten mango RM (24 isolates), rotten peach RP (4 isolates) and rotten cabbage RC (4 isolates).

Pectinase producing bacteria are screened for three parameters which are pre-requisite to consider pectinase producer to industrially important pectinase producers. Such bacterial pectinase producers fall in more than one category to be thermophilic and utilizes high pectin concentration.

\section{Effect of Incubation Temperature:}

Effect of incubation temperature for pectinase plate assay depicts that as the temperature increases the pectinase production lowers with reduced colony and zone size (Figure 3). This also provides basis of screening of potential thermophilic pectinase producers. Extremely thermophilic bacteria are part of our study. Trend of loss of bacteria not able to be screened for pectinase on increased temperature is smooth except for at 50 degrees which might be due to random error in the study. $28.7 \%$ of the producers (19 strains) in this study are thermophilic with one strain isolate number 72 being extreme thermophile with potential of producing pectinase at extreme temperature. Most thermophilic bacterial pectinase producers belong to rotten tomato sample. Other studies show similar results for isolation of pectinase producing bacteria from rotten fruits and vegetable samples particularly rotten tomato (Obafemi et al., 2019) and rotten mango (Reddy\& Saritha, 2015).

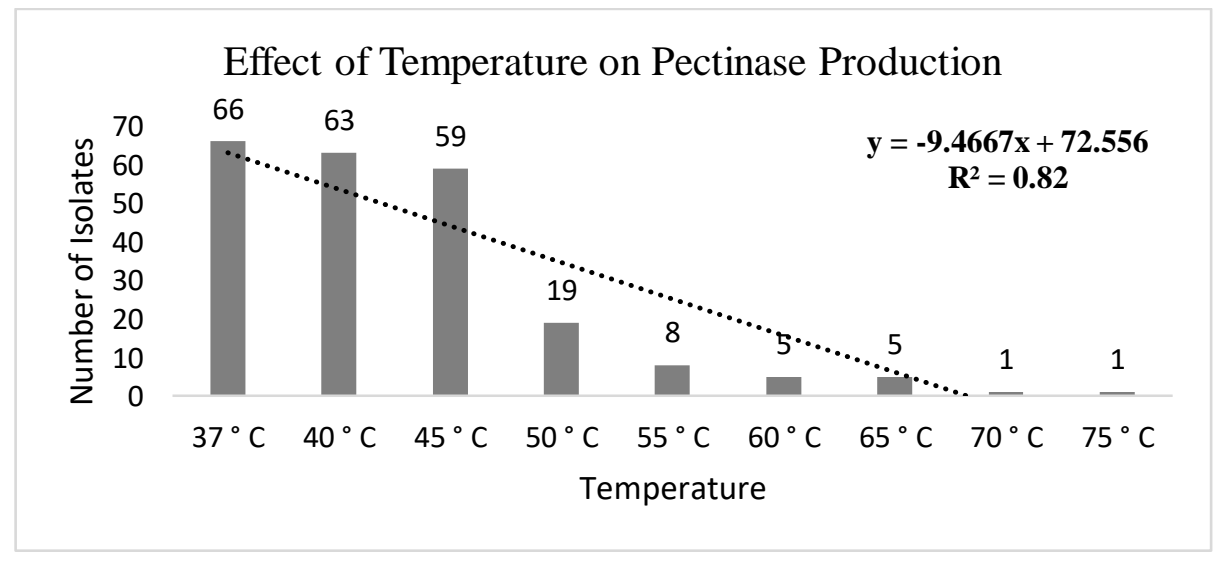

Figure 3: Effect of incubation temperature on pectinase production 


\section{Effect of Substrate Concentration:}

Number of isolates decreases with increment in pectin concentration in pectinase screening media (Figure 4). Initial screening was carried out at minimum pectin concentration to increase sensitivity and specificity of the test. With increasing pectin concentration, the number of isolates is reduced but high pectin utilising bacteria have been screened. Total 28 strains have pectin degrading properties among which six isolates have found to be pectinolytic for $2.5 \%$ pectin containing medium. Such bacterial pectinase producers belong to rotten tomato sample.

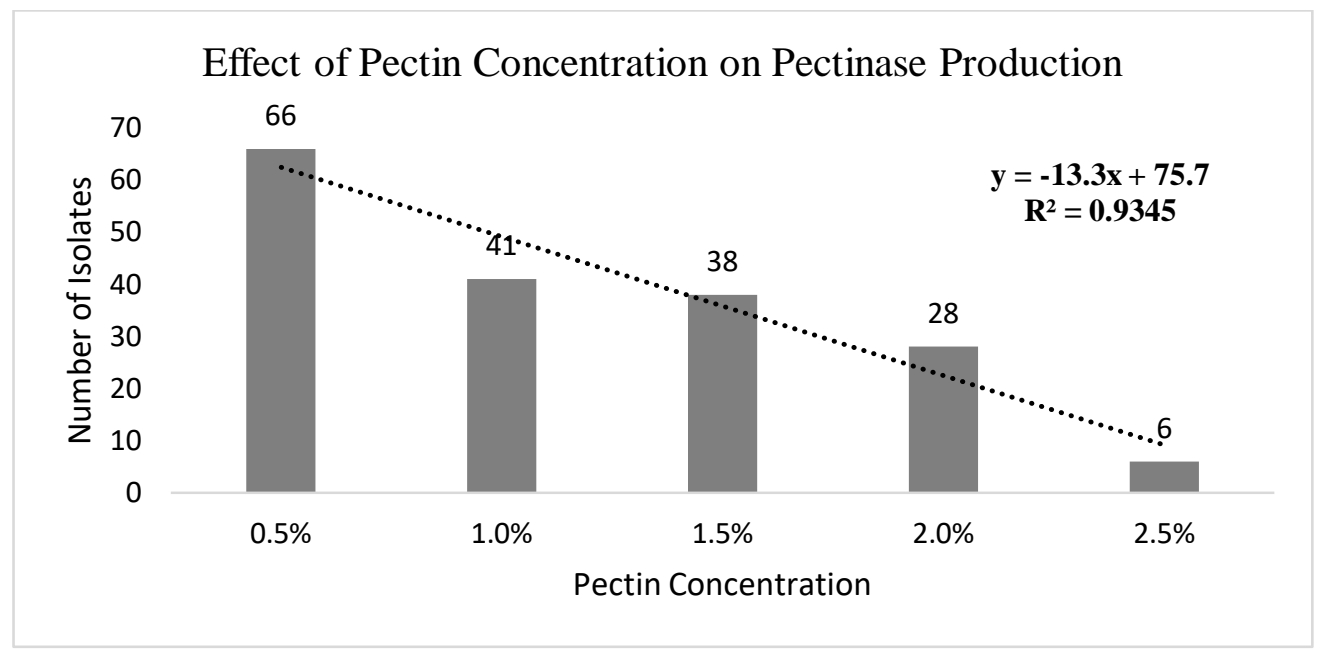

Figure 4: Effect of pectin concentration on pectinase production

\section{Effect of Incubation Time:}

All sixty-six cultures produced pectinase for 48 hours. However, as incubation time exceeded till $120^{\text {th }}$ hour, decrease in number of bacteria producing strains was observed depicting all cultures have potential to effective maximum pectinase producers with fermentation time range of 24 hours to 48 hours (Figure 5).

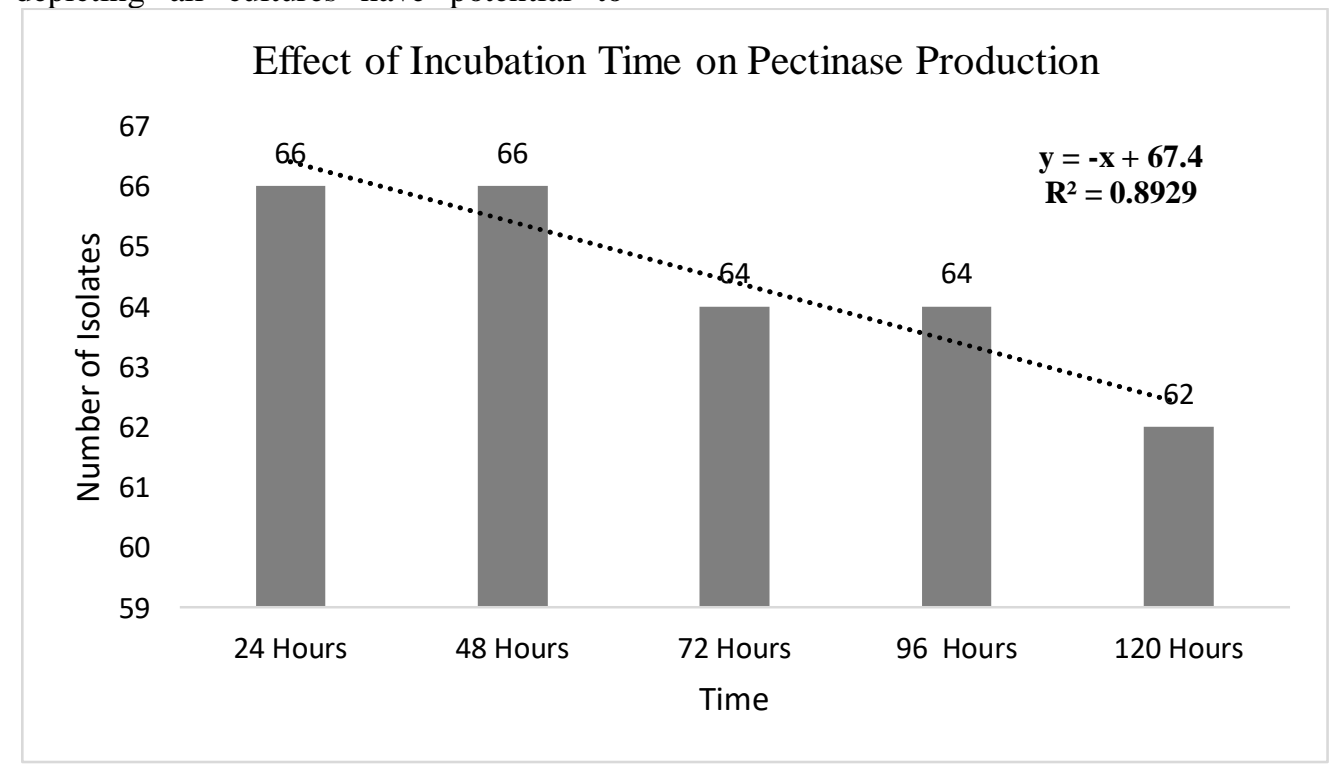

Figure 5: Effect of incubation time on pectinase production

Morphological and Biochemical Characterization: Summary of the biochemical and morphological studies are presented in table 1 . The results of the experiments were compared to Bergey`s manual of Determinative Bacteriology. Among sixty-six strains, twenty-two strains were identified as Bacillus sp. 
Pectinase Producers from Rotten Fruits and Vegetable Samples: Isolation, Screening and Characterization

isolated from rotten tomato (13 isolates), rotten mango ( 8 isolates), rotten cabbage ( 1 isolates) and

none from rotten peach sample.

Table 1: Screening and characterization of 7 industrially important pectinase producing bacterial strain

\begin{tabular}{|c|c|c|c|c|c|c|c|c|}
\hline \multicolumn{2}{|c|}{ Isolate no. } & 7 & 65 & 69 & 70 & 72 & 75 & 80 \\
\hline \multicolumn{2}{|c|}{ Sample } & RT & RT & RT & RT & RT & RT & RT \\
\hline \multicolumn{2}{|c|}{$\begin{array}{l}\text { Incubation } \\
\text { Temperature }\end{array}$} & $37-65^{\circ} \mathrm{C}$ & $37-60^{\circ} \mathrm{C}$ & $37-60^{\circ} \mathrm{C}$ & $37-55^{\circ} \mathrm{C}$ & $37-75^{\circ} \mathrm{C}$ & $37-55^{\circ} \mathrm{C}$ & $37-45^{\circ} \mathrm{C}$ \\
\hline \multicolumn{2}{|c|}{ Pectin Utilization } & $0.5-2.5 \%$ & $0.5-2.5 \%$ & $0.5-2.5 \%$ & $0.5-2.5 \%$ & $0.5-2.5 \%$ & $0.5-2.5 \%$ & $0.5-2.5 \%$ \\
\hline \multicolumn{2}{|c|}{ Incubation Time } & $\begin{array}{l}24-120 \\
\text { hours }\end{array}$ & $\begin{array}{l}24-120 \\
\text { hours }\end{array}$ & $\begin{array}{l}24-120 \\
\text { hours }\end{array}$ & $\begin{array}{l}24-120 \\
\text { hours }\end{array}$ & $\begin{array}{l}24-120 \\
\text { hours }\end{array}$ & $\begin{array}{l}24-120 \\
\text { hours }\end{array}$ & $\begin{array}{l}24-120 \\
\text { hours }\end{array}$ \\
\hline \multicolumn{2}{|c|}{ Oxygen Requirement } & $\begin{array}{l}\text { Facultative } \\
\text { Anaerobe }\end{array}$ & Aerobe & Anaerobe & Aerobe & Aerobe & $\begin{array}{l}\text { Facultative } \\
\text { Anaerobe }\end{array}$ & Aerobe \\
\hline \multicolumn{2}{|c|}{ Gram Reaction } & + & + & + & + & + & - & + \\
\hline \multicolumn{2}{|c|}{ Size \& Shape } & Rods & Rods & Rods & Rods & Rods & Cocci & Rods \\
\hline \multicolumn{2}{|c|}{ Arrangement } & Scattered & Chains & Chains & Scattered & Chains & Chains & Scattered \\
\hline \multicolumn{2}{|c|}{ Catalase } & + & + & + & + & + & + & + \\
\hline \multicolumn{2}{|c|}{ Motility } & + & - & + & + & + & + & - \\
\hline \multicolumn{2}{|c|}{ Hydrogen Sulfide } & - & - & - & - & - & - & - \\
\hline \multirow{5}{*}{ 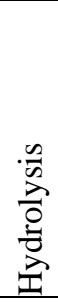 } & Starch & + & + & + & + & + & - & + \\
\hline & Gelatin & + & + & + & + & + & + & + \\
\hline & Tween 80 & + & + & - & + & - & + & - \\
\hline & Casein & - & + & + & - & - & - & + \\
\hline & $\begin{array}{l}\text { Carboxymethl } \\
\text { Cellulose }\end{array}$ & - & + & + & + & + & + & + \\
\hline \multirow{3}{*}{ 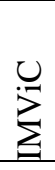 } & Indole & - & - & - & - & - & - & - \\
\hline & Methyl Red & + & + & + & + & + & - & + \\
\hline & Citrate & - & - & - & - & + & - & - \\
\hline \multirow{7}{*}{ 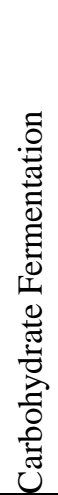 } & Glucose & + & + & + & + & $\oplus$ & + & + \\
\hline & Maltose & + & + & + & - & $\bigoplus$ & + & + \\
\hline & Lactose & - & - & - & + & $\bigoplus$ & - & + \\
\hline & Mannitol & - & + & + & - & $\oplus$ & - & + \\
\hline & Sucrose & + & + & + & $\bigoplus$ & $\bigoplus$ & - & + \\
\hline & Xylose & + & + & + & + & $\oplus$ & + & $\oplus$ \\
\hline & Glycerol & $\bigoplus$ & + & + & + & $\oplus$ & + & + \\
\hline \multicolumn{2}{|c|}{ Family } & $\begin{array}{l}\text { Bacillacea } \\
\mathrm{e}\end{array}$ & $\begin{array}{l}\text { Bacillacea } \\
\mathrm{e}\end{array}$ & Bacillaceae & Bacillaceae & Bacillaceae & $\begin{array}{l}\text { Neisseriace } \\
\text { ae }\end{array}$ & Bacillaceae \\
\hline \multicolumn{2}{|c|}{ Genus } & $\begin{array}{l}\text { Bacillus } \\
\text { sp. }\end{array}$ & $\begin{array}{l}\text { Bacillus } \\
\text { sp. }\end{array}$ & $\begin{array}{l}\text { Clostridiu } \\
\text { m sp. }\end{array}$ & Bacillus sp. & Bacillus sp. & - & Bacillus sp. \\
\hline
\end{tabular}

Conclusions:

Pectinases play important role in the field of biotechnology and in different industries. Pectinases have been produced by sundry workers using cost- effective substrates but still its production cost is high due to the instability or low activity of enzyme at elevated temperatures for longer period. This study has been focused on isolation, screening and 
characterization of bacterial pectinase producers to utilize pectin at different concentration, time and temperature. Further molecular characterization and optimization of pectinase production on conventional and agro-industrial waste containing pectin as substrate should be explored for maximum utilization of strains.

\section{References}

1. Ahmed I, Zia MA, Hussain MA, Akram Z, Naveed MT, Nowrouzi A. Bioprocessing of citrus waste peel for induced pectinase production by Aspergillus niger; its purification and characterization. Journal of Radiation Research and Applied Sciences. 2016 Apr 1;9(2):148-54.

2. Amin F, Bhatti HN, Bilal M, Asgher M. Improvement of activity, thermo-stability and fruit juice clarification characteristics of fungal exo-polygalacturonase. International journal of biological macromolecules. 2017 Feb 1;95:974-84.

3. Chatha SA, Asgher M, Iqbal HM. Enzyme-based solutions for textile processing and dye contaminant biodegradation-a review. Environmental Science and Pollution Research. 2017 Jun 1;24(16):14005-18.

4. Deng $Z$, Wang $F$, Zhou B, Li J, Li B, Liang $\mathrm{H}$. Immobilization of pectinases into calcium alginate microspheres for fruit juice application. Food Hydrocolloids. 2019 Apr 1;89:691-9.

5. Garg G, Singh A, Kaur A, Singh R, Kaur J, Mahajan R. Microbial pectinases: an ecofriendly tool of nature for industries. 3 Biotech. 2016 Jun 1;6(1):47.

6. Jayani RS, Saxena S, Gupta R. Microbial pectinolytic enzymes: a review. Process Biochemistry. 2005 Sep 1;40(9):2931-44.

7. Kashyap DR, Vohra PK, Chopra S, Tewari R. Applications of pectinases in the commercial sector: a review. Bioresource technology. 2001 May 1;77(3):215-27.

8. Kavuthodi B, Sebastian D. Review on bacterial production of alkaline pectinase with special emphasis on Bacillus species. Biosci Biotechnol Res Commun. 2018 Jan 1;11:18-30.

9. Kohli P, Gupta R. Alkaline pectinases: a review. Biocatalysis and Agricultural Biotechnology. 2015 Jul 1;4(3):279-85.

10. Li K, Meng K, Pan X, Ma R, Yang P, Huang H, Yao B, Su X. Two thermophilic fungal pectinases from Neosartorya fischeri P1: Gene cloning, expression, and biochemical characterization. Journal of Molecular Catalysis B: Enzymatic. 2015 Aug 1;118:70-8.

11. Mahesh M, Arivizhivendhan KV, Maharaja P, Boopathy R, Hamsavathani V, Sekaran G. Production, purification and immobilization of pectinase from Aspergillus ibericus onto functionalized nanoporous activated carbon (FNAC) and its application on treatment of pectin containing wastewater. Journal of Molecular Catalysis B: Enzymatic. 2016 Nov 1;133:43-54.

12. Obafemi YD, Ajayi AA, Taiwo OS, Olorunsola SJ, Isibor PO. Isolation of Polygalacturonase-Producing Bacterial Strain from Tomatoes (Lycopersicon esculentum Mill.). International Journal of Microbiology. 2019;2019.

13. Ortiz GE, Ponce-Mora MC, Noseda DG, Cazabat G, Saravalli C, López MC, Gil GP, Blasco M, Albertó EO. Pectinase production by Aspergillus giganteus in solid-state fermentation: optimization, scale-up, biochemical characterization and its application in olive-oil extraction. Journal of industrial microbiology \& biotechnology. $2017 \mathrm{Feb}$ $1 ; 44(2): 197-211$

14. Parveen S, Wani AH, Bhat MY, Koka JA, Fazili MA. Variability in production of extracellular enzymes by different fungi isolated from rotten pear, peach and grape fruits. Brazilian Journal of Biological Sciences. 2017 Dec 31;4(8):259-64

15. Reddy MP, Saritha KV. Bio-catalysis of mango industrial waste by newly isolated Fusarium sp.(PSTF1) for pectinase production. 3 Biotech. 2015 Dec 1;5(6):893-900.

16. Rehman HU, Siddique NN, Aman A, Nawaz MA, Baloch $\mathrm{AH}$, Qader SA. Morphological and molecular based characterization of pectinase producing Bacillus licheniformis from rotten vegetable. Journal of Genetic Engineering and Biotechnology. 2015 Dec 1;13(2):139-44.

17. Sharma HP, Patel H, Sugandha. Enzymatic added extraction and clarification of fruit juices-A review. Critical reviews in food science and nutrition. 2017 Apr 13;57(6):1215-27.

18. Shet AR, Desai SV, Achappa S. Pectinolytic enzymes: classification, production, purification and applications. Res J Life Sci Bioinform Pharm Chem Sci. 2018;4:337-48.

19. Sindhu, R., Aneesh, E.M., Rebello, S., Binod, P., Pandey, A. and Anju, M., 2017. Recent advancements in the production and application of microbial pectinases: an overview.

20. Soares MM, Silva RD, Gomes E. Screening of bacterial strains for pectinolytic activity: characterization of the polygalacturonase produced by Bacillus sp. Revista de Microbiologia. 1999 Dec;30(4):299-303.

21. Sohail M, Latif Z. Phylogenetic analysis of polygalacturonase-producing Bacillus and Pseudomonas isolated from plant waste material. Jundishapur journal of microbiology. 2016 Jan;9(1).

22. $\mathrm{Yu} \mathrm{P}, \mathrm{Xu}$ C. Production optimization, purification and characterization of a heat-tolerant acidic pectinase from Bacillus sp. ZJ1407. International journal of biological macromolecules. $2018 \quad$ Mar $1 ; 108: 972-80$ 